\title{
EDITORIAL
}

\author{
DOENÇA DE CHAGAS COMO ENDEMIA NA \\ AMAZÔNIA BRASILEIRA: \\ RISCO OU HIPÓTESE?
}

\section{CHAGAS' DISEASE AS ENDEMIC TO THE BRAZILIAN AMAZON: RISK OR HYPOTHESIS?}

Dois entre os maiores problemas da Amazônia - as migrações de populaçōes humanas de outras regiões e o desmatamento desordenados - constituem também os principais riscos de instalação da doença de Chagas como endemia naquela região.

Desde longa data se conhece a presença de reservatórios de Trypanosoma cruzi entre animais e vetores silvestres do parasito na Amazônia brasileira, entretanto, os relatos de casos humanos da doença são esporádicos, ocorrendo provavelmente de forma acidental, por ingestão de alimentos contaminados ou por contactos fortüitos com triatomíneos infectados. Esse fato decorre da não adaptação ainda de triatomíneos ao domicílio humano naquela região, exceto o Triatoma rubrofasciata, que embora domiciliado não tem hábitos antropofilicos.

Pelo menos 18 espécies de triatomíneos já foram encontrados na Amazônia brasileira: Belminus herreri; Cavernicola lenti; Cavernicola pilosa; Eratyrus mucronatus; Microtriatoma trinidadensis; Panstrongylus geniculatus; Panstrongylus lignarius; Panstrongylus rufotuberculatus; Rhodnius brethesi; Rhodnius nasutus; Rhodnius neglectus; Rhoanius pictipes; Rhodnius paraensis; Rhodnius prolixus; Rhodnius robustus; Triatoma maculata; Triatoma rubrofasciata e Triatoma rubrovárial 61214.

Quanto a última espécie, característica da região Sul do nosso país, há dúvidas sobre o seu achado ocasional na Amazônia, enquanto o Rhodnius prolixus foi encontrado nessa região uma única vez.

A situação dos triatomineos do Maranhão é bastante eclética e pouco definida. Várias espécies silvestres e domésticas mas não domiciliadas já foram ali descritas, parecendo em fase de transição de um ciclo para o outro. Vale lembrar que o Maranhão é zona de transição entre o Nordeste e a Amazônia.

Embora pelo menos 9 espécies de triatomineos silvestres da Amazônia brasileira já tenham sido encontradas albergando tripanosomas semelhantes ao cruzi - E. mucronatus, $M$. trinidadensis, $P$. geniculatus, $P$. lignarius, $P$. rufotuberculatus, $R$. pictipes, $R$. neglectus, $R$. paraensis e $R$. robustus 269131416 , parece não haver ainda evidências definitivas de domiciliação de qualquer dessas espécies, infectadas ou não, ao domicilio humano. $\mathrm{O}$ encontro de triatomíneos adultos no domicílio ou peridomicilio na região Amazônica, tem sido um achado ocasional, quando

Recebido para publicação em 15/06/90.
Two of the major problems facing the Amazonhuman migration from other areas and uncontrolled deforestation - also constitute the greatest risks that Chagas' disease will become endemic in this part of the country.

For some time now, it has been known that there are Trypanosama cruzi reservoir hosts among wild animals and vectors of the parasite in the Brazilian Amazon; however, reports of human cases of the disease have been sporadic, probably occurring at random due to ingesting contaminated food or to accidental contacts with infected triatominae. This is the result of the fact that triatominae have not yet adapted to human habitats in the area, except for Triatoma rubrofasciata, which in spite of its household existence does not have anthropophilic habits.

At least 18 species of triatominae have been found in the Brazilian Amazon: Belminus herreri; Cavernicola lenti; Cavernicola pilosa; Eratyrus mucronatus; Microtriatoma trinidadensis; Panstrongylus geniculatus; Panstrongylus lignarius; Panstrongylus rufotuberculatus; Rhodnius brethesi; Rhodnius nasutus; Rhodnius neglectus; Rhodnius pictipes; Rhodnius paraensis; Rhodnius prolixus; Rhodnius robustus; Triatoma maculata; Triatoma rubrofasciata and Triatoma robrovarial 61214.

Concerning the last species, characteristic of the southern part of our country, there are doubts as to its being occasionally found in the Amazon, while Rhodnius prolixus has been found only once here.

The situation of triatominae in Maranhão is quite eclectic and not well defined. A number of wild and domestic species, though of a nondomiciliary type, have been described there, apparently in a transition phase from one cycle to another. It should be recalled that Maranhão is a transition zone between the Northeast and the Amazon.

Although at least nine species of wild triatominae from the Brazilian Amazon have been found hosting trypanosomae similar to T. cruzi-E. mucronatus, $M$. Trinidadensis, $P$. geniculatus, $P$. lignarius, $P$. rufotuberculatus, $R$ pictipes, $R$. neglectus, $R$. paraensis and $R$. robustus 269131415 , it seems that there is still no definitive evidence that any of these species, infected or not, have become domiciliary for 
Editorial. Coura JR. Chagas' disease as endemic to the Brazilian Amazon: Risk or hypothesis? Revista da Sociedade Brasileira de Medicina Tropical 23:67-70, abr-jun, 1990

esses insetos são atraídos pela luz ou levados mecanicamente com a lenha, com material de construção, como folhas de palmeiras colhidas na mata para cobertura das casas, etc.

Desde que Chagas em 1924 confirmou como cruzi tripanosomas encontrados em 1922 por AbenAthar, em macacos da espécie Saimiri sciureus (macaco de cheiro), no Estado do Pará, diversas espécies de mamiferos silvestres entre marsupiais, quirópteros, roedores, desdentados e primatas da Amazônia, têm sido descritas, por vários autores, como portadores de Trypanosoma cruzi, "semelhantes" ou do "tipo cruzi"78.

A confirmaçāo de Chagas (1924) sobre a presença de $T$. cruzi em reservatório silvestre na região amazônia, onde não existia casos humanos da doença, foi extremamente importante para confirmar a sua própria hipótese de que a doença por ele descoberta teria sido primitivamente uma enzootia exclusiva de animais silvestres, adaptadas posteriormente aos animais domésticos e ao homem. A comprovação desse fato é de grande importância para o estudo dos riscos de instalação da doença de Chagas como endemia em populações humanas daquela região.

Desde que Shaw, Lainson e Frahia ${ }^{16}$ descreveram os primeiros 4 casos autóctones da doença de Chagas em Belém do Pará até 1988, apenas 26 casos humanos da doença haviam sido descritos na Amazônia brasileira: 10 no Pará, 9 no Amapá, 4 no Maranhão, 2 no Amazonas e 1 no Acre, todos como achado ocasional e caracteristicas de casos agudos. É possível que outros casos tenham sido observados na região Amazônica e não publicados.

Apesar dos poucos casos humanos da doença de Chagas descritos até agora na Amazônia brasileira, essa região está progressivamente sob maior risco da instalação da doença como endemia, pelos seguintes motivos: a) Desmatamento e colonização desordenados com alteração do balanço ecológico entre reservatórios e vetores silvestres. b) Adaptação de reservatórios (marsupiais) e vetores silvestres ao peri e intradomicílio, como única alternativa alimentar. c) Migração de populações humanas infectadas de áreas endêmicas, acompanhadas de reservatórios domésti$\cos$ (cães) e/ou transportando acidentalmente em suas bagagens vetores já adaptados ao domicílio. Em síntese, os riscos da instalação da endemia chagásica na Amazônia estariam ligados a transposição do ciclo silvestre para o doméstico naquela área e do ciclo doméstico de áreas endêmicas para a Amazônia.

Os desmatamentos e a colonização desordenados da Amazônia constituem hoje uma das maiores preocupações da sociedade consciente do nosso país e humans. Adult triatominae have only been found occasionaly in or around residences in the Amazon, these insects having been attracted by light or physically brought in with firewood or construction materials such as palm leaves gathered to use as roofing.

Since 1924, when Chagas confirmed like cruzi Trypanosomes found in 1922 by Aben-Athar in squirrel monkeys (Saimiri sciureus) in the state of Pará, several species of wild mammals, including marsupials, Chiroptera, rodents, Edentata and primates native to the Amazon have been described by various authors as carriers of Trypanosoma cruzi, "similar to" or of the "cruzi type"7 8.

Chagas' confirmation (1924) that T. cruzi existed in wild reservoir hosts in the Amazon, where there were no human cases of the disease, was extremely important as proof of his own hypothesis that the disease he had discovered had in primitive times been an enzootic found only in wild animals, subsequently adapted to domestic animals and man. Verification of this fact is highly important to the study of the risks of Chagas' disease becoming endemic in human populations in this area.

Since Shaw, Lainson and Frahial6 described the first 4 autochthonous cases of Chagas' disease in Belem do Pará in 1969, only 26 human cases of the disease have been described in the Brazilian Amazon: 10 in Pará, 9 in Amapá, 4 in Maranhão, 2 in Amazonas and 1 in Acre, all sporadically found and with the characteristics of acute cases. It is possible that other cases have been observed in the Amazon, and not published.

Despite the few human cases of Chagas' disease described up till now in the Brazilian Amazon, this area is progressively exhibiting a higher risk that the disease will become endemic, owing to the following reasons: a) Uncontrolled deforestation and colonisation that is altering the ecological balance between reservoir hosts and wild vectors. b) The adaptation of reservoir hosts (marsupials) and wild vectors to the peripheral and intradomiciliary areas, as a sole feeding alternative. c) Migration of infected human populations to endemic areas, accompanied by domestic reservoir hosts (dogs) and/or accidentally carrying in their baggage vectors already adapted to residences. In short, risks that Chagas' disease will become endemic to the Amazon appear to be linked to the transposition of the wild cycle to the domestic cycle in that area, and from the domestic cycle in endemic areas to the Amazon. 
motivo de grande especulação internacional pela possibilidade do seu crescimento exponencial ${ }^{10}$. Vários estudos sobre o assunto têm sido feitos recentemente e não serão aqui discutidos por falta de espaço. Com o desmatamento extensivo há forçosamente o afastamento dos animais silvestres para outras áreas, com tendência dos triatomíneos a se adaptarem a fontes alimentares alternativas no peri e intradomicílio. Barreto 5 em estudo sobre reservatórios e vetores do $T$. cruz $i$ analisa em profundidade as conseqüências das modificações dos focos naturais. Forattinill e Aragão ${ }^{34}$ estudaram com detalhes a pré-adaptação e origem da domiciliação de triatomíneos no Brasil, confirmando a nossa afirmação.

Finalmente os movimentos migratórios desordenados do Sul, Sudeste, Nordeste e Centro-Oeste para a região Amazônica, crescentes nos últimos anos, têm sido responsáveis pela manutenção e exacerbação de várias endemias parasitárias em nosso país, a exemplo da malária. No caso da doença de Chagas, embora com mecanismos de adaptação mais lentos, é talvez um dos mais graves riscos de transposição de uma doença endêmica para a Amazônia, que assistiremos até o século vinte e um, se as seguintes providências não forem tomadas: a) Redução e ordenação dos desmatamentos, principalmente na periferia dos aglomerados populacionais. b) Vigilância constante sobre a adaptação de triatomíneos silvestres ou de transposição de triatomineos e reservatórios domésticos de áreas endêmicas para a Amazônia e c) Formulação de uma politica global de ocupação e colonização da Amazônia, que preserve ao mesmo tempo a natureza e o desenvolvimento econômico e social da região.

\section{ACKNOWLEDGEMENTS}

The author would like to thank Dr. Leonidas de Mello Deane for reading this manuscript and making a number of valuable suggestions to improve it, as well as Drs. Angela Cristina V. Junqueira, Cristina Maria Giordano and Ilra R.K. Funatsu for their bibliographical research and suggestions.
Uncontrolled deforestation and colonisation in the Amazon are currently among great concerns aware citizens of our country, and give rise to great international speculation regarding the possibility that they will increase exponentially. ${ }^{10}$ Several studies on the matter have been carried out recently and will not be discussed here due to lack of space. With wideranging deforestation, wild animals will perforce be driven into other areas, with a tendency for triatominae to become adapted to alternative food sources in periand intradomicilary areas. Barreto ${ }^{5}$, in his study of $T$. cruzi reservoir hosts and vectors, gives a painstaking analysis of the consequences of modifying natural foci. Forrattini ${ }^{11}$ and Aragão ${ }^{3} 4$ have carried out a detailed study of the preadaptation and origin of the domiciliary activity of triatominae in Brazil,thus confirming our assertion.

Finally, uncontrolled migratory movements from the south, southeast, northeast and west-central areas toward the Amazon, on the rise during recent years, have been responsible for maintaining and exacerbating various parasitic endemic diseases in our contry, such as malaria. In the case of Chagas' disease, although its adaptation mechanisms are slower, it poses one of the most serious threats of transposing an endemic disease into the Amazon, which we will begin to note in the 21 st century, unless the following precautions are taken: a) Reduction and control of deforestation, mainly on the periphery of population centres. b) Constant surveillance of the adaptation of wild triatominae or the transposition of triatominae and domestic reservoir hosts from endemic areas to the Amazon. c) Formulation of a global policy for occupying and colonising the Amazon, which would simultaneously preserve nature and the socioeconomic development of the area.

\section{REFERENCES}

1. Almeida FB. Triatomíneos da Amazônia. Encontro de três espécies naturalmente infectadas por Trypanosoma semelhante ao cruzi, no Estado do Amazonas (Hemiptera, reduviidae). Acta Amazônica 1:89-93, 1971.

2. Almeida FB, Machado PA. Sobre a infecção do Panstrongylus geniculatus pelo Trypanosoma cruzi em Manaus, Amazonas, Brasil. Acta Amazônica 1(2):71-75, 1971.

3. Aragão MB. Sobre a domiciliação dos triatomíneos. Revista da Sociedade Brasileira de Medicina Tropical 14:13-27, 1981.

4. Aragão MB. Domiciliação de triatomíneos ou préadaptação à antropofilia e à ornitofilia(?). Revista de Saúde Pública São Paulo 17:51-55, 1983.

5. Barreto MP. Estudos sobre reservatórios e vectores silvestres do Trypasonoma cruzi. XXII. Modificaçōes 
Editorial. Coura JR. Chagas' disease as endemic to the Brazilian Amazon: Risk or hypothesis? Revista da Sociedade Brasileira de Medicina Tropical 23:67-70, abr-jun, 1990

dos focos naturais da tripanosomose americana e suas conseqüencias. Revista da Sociedade Brasileira de Medicina Tropical 1:167-173, 1967.

6. Brazil RP, Silva AR, Albarelli A, Vale JF. Distribuição e infeç̧ão de triatomíneos por trypanosoma do tipo cruzi na Ilha de São Luis-Maranhão. Revista da Sociedade Brasileira de Medicina Tropical 18:257-260, 1985.

7. Deane LM. Tripanosomídeos de mamíferos da região amazônica. I - Alguns flagelados encontrados no sangue de mamiferos silvestres do Estado do Pará. Revista do Instituto de Medicina Tropical de São Paulo 3:15-28, 1961.

8. Deane LM. Animal reservoirs of Trypanosoma cruzi in Brazil. Revista Brasileira de Malariologia e Doenças Tropicais 16:27-48, 1964.

9. Deane MP, Damasceno RMG, Encontro de Panstrongylus lignarius naturalmente infectado por tripanosoma do tipo cruzi e algumas notas sobre a biologia. Revista do Serviço Especial de Saúde Pública 2:809-815, 1949.

10. Fearnside PM. Desmatamento na Amazônia brasileira: com que intensidade vem ocorrendo? Acta Amazônica 12:579-590, 1982.

11. Forattini OP. Biogeografia, origem e distribuição da domiciliação de triatomíneos no Brasil. Revista de Saúde Pública de São Paulo 14:265-299, 1980.
12. Lent $\mathrm{H}$, wygodzinsky. Revision of the triatominae (Hemiptera, reduvildae), and their significance as vectors of Chagas'disease. Bulletin American Museum Natural History, New York 63:520, 1979.

13. Miles MA, Arias JR, Souza AA. Chagas'disease in the Amazon Basin. V. Periurban palms as habitats of Rhodnius robustus and Rhodnius pictipes - triatomine vectors of Chagas'disease. Memórias do Instituto Oswaldo Cruz 78:391-398, 1983.

14. Miles MA, Souza AA, Póvoa M. Chagas'disease in the Amazon Basin: III. Ectopes of ten triatomine bug species (Hemiptera, reduviidae) from the vicinity of Belem, Para, State, Brazil. Journal of Medical Entomology 18:266-278, 1981.

15. Rodrigues BA, Mello GB. Contribuiçào ao estudo da tripanosomiase americana. Memórias do Instituto Oswaldo Cruz 37:77-90, 1942.

16. Shaw J, Lainson $R$, Fraiha $H$. Considerações sobre a epidemiologia dos primeiros casos autóctones de doença de Chagas registrados em Belém, Pará, Brasil, Revista de Saúde Pública, São Paulo 3:153-157, 1969.

José Rodrigues Coura

Departamento de Medicina Tropical

Instituto Oswaldo Cruz

Rio de Janeiro, RJ 